\title{
Agility of Mobile Banking and Performance of Commercial Banks in Kirinyaga County, Kenya
}

\author{
Lydiah Wamucii Karimi BBIT, MBA ${ }^{1 *}$, Dr. Josphat K. Kyalo BSC, MSC (IS), PhD (MIS) ${ }^{2}$ \\ ${ }^{1}$ (MIS - Candidate), ${ }^{2}$ Lecturer; Department of Management Science School of Business; Kenyatta University P.O BOX 12188-10100, Nyeri, Kenya
}

\author{
Article History \\ Received: 27.01 .2021 \\ Accepted: 25.03 .2021 \\ Published: 30.03.2021 \\ Journal homepage: \\ https://www.easpublisher.com
}

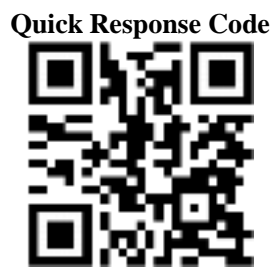

Abstract: The retail marketplace is witnessing a monumental change in consumer buyer behaviors, as hundreds of millions of people now prefer to sit at home and do almost all their daily activities on the mobile phones or computers through the internet. Firms like Amazon, Apple, and E-bay among others, are building or transforming their business models to generate sales, improve loyalty and generate additional revenue. Consequently, the commercial banks have joined the bandwagon by offering flexibility with greater focus on improving performance by introducing mobile banking. The current study endeavored to establish the relationship between mobile banking agility and performance of commercial banks in Kenya. Previous studies have shown that there are several challenges in the banking industry related to mobile banking such as low number of mobile banking transactions, slow uptake of mobile banking applications, poor security in the mobile banking platforms and poor data storage in the mobile banking platforms. The study established relationship between agility of mobile banking and performance of commercial banks in Kirinyaga County, Kenya. The study used purposive sampling with a target population is 6 registered commercial banks, with 140 employees and sample size are 62 IT specialists and mobile banking officers. Inferential analysis was used to evaluate significance of the hypothesis. The study findings revealed that agility of mobile banking explained $35.4 \%$ of bank performance of the registered commercial banks in Kirinyaga County. Consequently, the study submitted that, bank management should endeavor to embed collaboration, self-reinvention by putting technology first and change the culture by focusing on the customer.

Keywords: Mobile Banking Determinants, Mobile Agility, Banking Transaction, Mobile Banking Applications, Banking Security, Mobile Data Security, Services Authentication, Commercial Banks Performance.

Copyright (C) 2020 The Author(s): This is an open-access article distributed under the terms of the Creative Commons Attribution 4.0 International License (CC BY-NC 4.0) which permits unrestricted use, distribution, and reproduction in any medium for non-commercial use provided the original author and source are credited.

\section{INTRODUCTION}

In the today's competitive environment all over the world, service organizations and in particular the banking sector have realized that in order to keep their customers and gain competitive advantage, an important issue that needs to be kept into consideration is improving the quality of services [1]. According to Cohen [2] the world has also become increasingly enthusiastic about doing business in the cyber space, across the internet and World Wide Web. Mobile banking is a system that allows customers of a financial institution to conduct a number of financial transactions through a mobile device such as mobile phone or tablet [3].

Banks and Financial Institutions (FI) are in the business of financial intermediation that is channelizing investible financial resources to investment opportunities [4]. According to Aneesh et al., [1] the significance of technology in enabling the banking sector to deal with changing customer demands, improve operational efficiency, and enhance regulatory compliance is increasingly recognized by banks across the globe. This is evident by the expected growth in IT spending by the banking sector which is predicted to grow at a healthy rate of $3.8 \%$ during $2009-13$ to reach $\$ 63.6$ billion in 2013. The future fate of banks appears to lie in the mobile-obsessed hands of the millennial generation, with "Millennials" emerging as the most lucrative age group for financial product sales world over [3]. According to FSD Annual report (2018) "Millennials", consumption of mobile digital and wallet size had become lead indicators of performance for financial institutions.

In Iran, Hooman, Mostafa, and Hasan [5] study on the effect of quality of electronic banking services on agility of a bank established that the quality of the electronic banking services had a significant effect on the bank's agility. Additionally, the quality of electronic banking services was found to have effects on the service system quality. Whereas, the system service quality, also affects the employees' behavior. For that 
reason, they concluded that the electronic services quality and the bank's agility affect the personnel behavior quality through the mediated effect of the service system quality.

According to Guitterez and Singh [6] mobile banking is the use of mobile phones to conduct financial and banking transactions. Further suggestions show that mobile banking also refers to the delivery and accessibility of bank-related financial services with the aid of mobile telecommunication devices. The introduction of mobile banking has revolutionized and redefined the way banks operate. As technology is now considered as the main contribution for the organizations ${ }^{\text {ee }}$ success and as their core competencies. So the banks, be it domestic or foreign are investing more on providing customers with the new technologies through mobile banking.

In Africa, Campbell and Frey [7] study revealed that, rapid changes in new banking technologies, a rise in the variety of demands, the customers' banking needs, and a decrease in the costs of the customer attrition, have made movement towards agile banking a requirement for banks. In an agile bank, raising the quality of the customer services can be expected, which accompanied by a higher speed, is an increase in the number of new services and a rise in the degree of keeping the existing customers and attracting new customers.

In Kenya, Mobile money has advanced as great competition to financial institutions. Initially, cellular phones were developed to improve communication [8]. Financial institutions then presented Information and Communication Technology (ICT) as a development to the banking networks. This consequently permitted the customers to have access to information relating to their accounts [9].

Mobile phone service providers have further introduced mobile money services into the financial sector by presenting a variety of different financial services through their various networks. The CBK and the Communication Commission of Kenya (CCK) have since legalized service providers to provide mobile money services as there appears to be no amnesty as the competition in the mobile money business is still growing with the entry of new money transfer systems which have allowed transactions across all mobile telephone service providers example M-pesa. Kigen [10], study established that, the impact of mobile banking on transaction costs of financial institutions had considerably reduced the transaction costs noticeably though they were not felt directly by the banks because of the then small mobile banking customer base.

\section{Performance of Commercial Banks in Kenya}

The financial soundness of a financial institution may be strong or unsatisfactory varying from one bank to another. According to Mugembe [11], external factors such as: deregulation, lack of information among bank customers and homogeneity of the services bank offer do cause bank failure. The activities undertaken in m-banking contribute to the financial soundness of the commercial banks in Kenya. Some useful measures of financial performance are coined into what is referred to as CAMELS (Capital adequacy, Asset quality, and Management, Earning, Liquidity and Sensitivity analysis) which guide the banking sector [12]. According to Wachira [13] findings on the relationship between financial performance and camel rating of commercial banks in Kenya, the justification for considering CAMEL measures of performance is basically because CAMELS ratings is able to determine a bank's overall condition and also identifies its strengths and weaknesses in Financial, Operational and Managerial aspects.

According to CBK reports [14] the Kenyan banking sector registered an improvement in performance with the size of assets, loan and advances, deposit base and profits before tax improving. The number of bank customer deposits and loan accounts increased. The banking sector aggregate statement of financial position also expanded. Deposit base grew, the number of deposit accounts increased and capital levels and shareholders' funds increased. Profitability also increased. The components of expenses were staff costs, interest on deposits and others.

Financial performance refers to the financial soundness where depositors' funds are safe in a stable banking system [15]. The financial soundness of a financial institution may be strong or unsatisfactory varying from one bank to another. According to Mugembe [11], external factors such as: deregulation, lack of information among bank customers and homogeneity of the services bank offer do cause bank failure. The activities undertaken in m-banking contribute to the financial soundness of the commercial banks in Kenya. Some useful measures of financial performance are coined into what is referred to as CAMELS (Capital adequacy, Asset quality, and Management, Earning, Liquidity and Sensitivity analysis) which guide the banking sector [13].

\section{Mobile Banking Agility}

Generally, mobile banking is the act of making financial transactions on a mobile device that is cell phone, tablet, etc. [16]. Thus mobile banking agility in the banking sector refers to the extent to which commercial banks thrive in the competitive era by adopting the growing trends through mobile banking in a more agile approach [17].

In today's competitive and customer-centered environment, customer satisfaction is not only a competitive tool but also a competitive need for service industry like the backing sector [17]. For that reason, business firms need to develop such competencies that 
enable them to respond to rapid changes like activating mobile banking agility system. Mutua [14], highlighted that, without a doubt 'agile' firms simultaneously seek to provide high quality products, without defects, within short waiting times, along with keeping upgrading capabilities as well as the ability to reorganize the system specifically the banking application, banking transactions, banking security and banking data as some of the key elements having an effect on satisfaction in the system.

Telstra [17] research found that UK millennial average wallet size has now overtaken all other demographic segments by the largest margin compared to other countries studied. A comparative study of UK bank account data by Tchouassi [17], found that Barclays Bank has the largest proportion of millennials among its customer base (42\%), the largest main bank market share $(16 \%)$ and Barclays Bank millennial customers are most likely to engage with the bank via mobile banking - over $70 \%$ do so each month.

The advent of M-banking was fostered by competition from telecommunication industry mainly safaricom with their Mpesa services to their customers and Zain (formerly Airtel) with Zap services. These services facilitated the customers to deposit money into their account, transfer money to other user for instance sellers of goods and services, relatives and friend; this brought convenience. The banking sector has had to adopt technological change to remain competitive. In search of competitive advantages in the technological financial service industry, banks have acknowledged value of differentiate themselves from others financial institution through new service distribution channels.

Mobile banking has transformed the way people in the developing world transfer money and now it is poised to offer more sophisticated banking services which could make a real difference to people's lives. This type of banking can offer a wide variety of services ranging from account information, which has to do with alerting the customers on the updates and transactions on their account through their mobile phones. People receive short messages on their phones informing them of their immediate transactions in their bank accounts. Also, they help in payments (utility bills), deposits, withdrawals, transfers, purchase airtime, request bank statements and perform other crucial banking tasks, all in real time over their mobile phones [14].

\section{Statement of the Problem}

In the Kenyan banking sector, Cytonn 2020, report highlighted that; the core earnings per share recorded a weighted decline of $33.6 \%$ in H1'2020 and that, asset quality for listed banks deteriorated in H1' 2020 with the gross NPL ratio rising by $1.6 \%$ points to $11.6 \%$ from $10.0 \%$ in $\mathrm{H}^{\prime}{ }^{\prime} 2019$. The decline in the earnings was mainly attributable to the increased provisioning on the back of the subdued business environment. Side by side with Clark [18] revelations that, majority of people in Kenya don't use M banking as a payment system as per Steadman Group report of January, 2011 hence it is evident that M banking adoption is growing at a slower pace in comparison to the population that is eligible to have them [18].

With the introduction of mobile banking applications, the banking industry was projecting a boom in the number of transactions which would in turn result to good performance for the commercial bank. This seems not to be the case; people are still very sceptical on using the mobile application to do their daily banking transactions. Okiro and Ndung'u [19] did a study on the impact of mobile and internet banking on the performance of financial institutions in Kenya. The findings were that various challenges face mobile banking among them being slow transaction processing, service provider system delays, and high cost of transactions, daily withdrawal limits and frauds.

Commercial banks today face challenges that range from debt crises to extremely tight competition in the market. Kigen [10] hypothesized that, Speed, not size, will drive bank profits in this post-financial-crisis world. He further proposed that banks can become agile over time by taking practical steps in the short term to build a foundation for a more flexible business model in the long run. With introduction of mobile services in the banking industry, the commercial banks are faced with the challenge of embracing the new technological advances in the industry and the mobile application uptake is very low even for those that are trying to use the technology as a competitive advantage.

Several studies have been conducted on the concept of mobile banking risk. However, as argued by Islam [20] the concerns for mobile banking risks in most cases are fears born more of perception than reality. Despite existence of some of these threats, there are security controls, which affectively and substantially mitigate their risk. Thus, some perceived threats do not always constitute significant risks. Moreover, security practices and threats are continuously evolving as mobile technology advances. This creates an ever-growing demand for understanding the significant prevailing and potential mobile banking security risks in given contexts. In Africa, a study by Masamila [21] to explore the state of mobile banking and its associated threats in Tanzania identified viruses and malwares, which can potentially lead to eavesdropping on user activities, stealing of sensitive information, destruction of stored information, deactivation or activation of applications or disablement of a device as the main security concerns for firms that provide mobile banking.

According to FSD Annual report 2018 Mobile banking in Kenya has completely transformed the banking industry and any commercial bank operating in 
Kenya can only ignore that fact at its own peril. This study aims to investigate the low number of transactions, few mobile applications, poor security and poor data storage witnessed in the existing mobile applications. This study therefore seeks to fill this knowledge gap by examining the mobile banking agility and performance of commercial banks in Kirinyaga County, Kenya.

\section{Research Objective and Hypothesis}

The research study objective was to investigate the effect of agility of mobile banking and the performance of the commercial banks in Kirinyaga County, Kenya. The research study hypothesis was that there was no statistically significant effect of agility of the mobile banking and the performance of the commercial banks in Kirinyaga County, Kenya

\section{EMPIRICAL REVIEW}

In his study, Kithaka [22] analysed the effects of mobile banking on the financial performance of commercial banks in Kenya where he established that there were mobile banking variables influencing the financial performance of commercial banks in Kenya, which are annual amount of money moved through mobile banking, number of users of mobile banking, capital adequacy, asset quality, bank liquidity and management efficiency and they influenced it positively.

Tchouassi [17] on the other hand sought to find out whether mobile phones really work to extend banking services to the unbanked using empirical Lessons from Selected Sub-Saharan Africa Countries. This study sought to discuss how mobile phones could be used to extend banking services to the unbanked, poor and vulnerable population. The study noted that poor, vulnerable and low-income households in SubSaharan Africa (SSA) countries often lacked access to bank accounts and faced high costs for conducting basic financial transactions. The mobile phone presented a great opportunity for the provision of financial services to the unbanked. In addition to technological and economic innovation, policy and regulatory innovation was needed to make these services a reality.

Muisyo, Alala \& Musiega [23] also evaluated the effect of mobile money services on banking institutions in Kenya. The study focused on commercial banks operating in Kakamega County. The study reveals that the introduction of a myriad of mobile money services (MMS) by various mobile money service providers to customers has become common in the recent years as a way of gaining competitive advantage through diversification, maintaining customer loyalty and increasing market share in order to grow their profitability and improve their financial position. The roll out of these services in developing countries has generated a lot of interest among various players in the financial sector of the economy. Such services include person to person $(\mathrm{P} 2 \mathrm{P})$ mobile money transfer (MMT), pay bill services, loan to customers and access to a wide range of banking services for instance account balances, mini statements, transfer of money from one's mobile line account to one's own bank account. This provides both an opportunity and a challenge to the banking industry, one of the leading industries in the financial sector.

According to Kathuo, Rotich and Anyango [16] study on the effect of mobile banking on the financial institutions of banking institutions in Kenya, the number of mobile banking transactions has tremendously increased in the last five years since the introduction of M-banking. The study thus concludes that, banks that have adopted M-banking services have to a large extent increased their customer outreach, and hence have improved their financial performance. The findings revealed that many mobile banking products are being offered by banks such as Fund Transfer between Accounts/ E-funds transfer, Bill Payment, order for cheque books and bank statements and therefore concluded that the financial performance of the banks that provide these mobile banking products has improved because they ensure efficiency of the banking services.

Mobile banking application is basically a service provided by commercial bank or rather financial institutions that allows its customers to conduct financial transactions remotely using a mobile device [9]. In Kenya, commercial banks have been riding on the digital revolution wave to improve their operational efficiency. Consequently, increased adoption of alternative channels of transactions such as mobile, internet and agency banking, has led to increased transactions through mobile banking application [24].

Munyoki [25] study which investigated the effect of mobile banking on the performance of banking institutions in Kenya established that, the number of mobile banking transactions has tremendously increased in the last five years since the introduction of M-banking. Additionally, the study revealed that many mobile banking products are being offered by banks for instance fund transfer between accounts/ E-funds transfer, bill payment, order for cheque books and bank statements and therefore concluded that the financial performance of the banks that provide these mobile banking products has improved because they ensure efficiency of the banking services.

Mutua [14] research work which analyzed the effects of mobile banking on the financial performance of commercial banks in Kenya demonstrated that, there exist a weak positive relationship between mobile banking and the financial performance of commercial banks in Kenya. Consequently the study proposed that, policy makers should keep a keen eye on the developments of mobile banking as it is a new platform for competition among commercial banks as the world 
moves into a digital age to ensure it does not lose its regulatory role.

Kingoo [26] study on the relationship between electronic banking and financial performance of commercial banks in Kenya in which he focused on the microfinance Institutions in Nairobi found out that indeed embracing electronic banking has a positive relationship with the financial performance of commercial banks in Kenya. The researcher however observed that, he looked at the wider electronic banking whereas this study will only concentrate on mobile banking agility.

Mwange [27] study which analyzed the impact of mobile banking on financial performance of commercial banks in Kenya established that, Mobile Banking has a moderate influence on profitability of commercial banks in Kenya. Accordingly, there exists positive relationship between mobile banking and bank performance. Based on the summary of the major findings of the study it can be concluded from the investment in mobile banking measured and the number of mobile banking transactions by the banks have a positive relation to the Return On Asset (ROA) in that a unit increase in each / or all would result in an increase in the performance indicator ROA.

Mobile banking just any other technology is susceptible to various forms of risks and threats. In fact, most of these risks are launched on the mobile banking application. Consequently, risks emanating from mobile banking have been regarded as the greatest hindrance to building sustainability in the performance of this young and promising industry [8]. According to Kopchik, [28] security concerns present significant challenges for financial institutions providing mobile banking services, and each delivery channel poses unique risks for institutions and customers.

Ching [29] study on the factors affecting Malaysian mobile banking adoption established that, one of the main and most important issues faced by the users is security which works as obstacle in adoption of new technology. He further highlighted that, the individual may worry about security like loss of connection, data transmitted and loss of money concern while using mobile banking.

According to Valverde \& Rodriguez [30] study on the determinants of bank margins in European banking, the mobile banking services providers must develop such mechanisms which ensure the security of financial transactions and very sensitive data. Additionally, they submitted that, the security must fool proof and not allowed to unauthentic usage and that the sensitive information must only be used by related persons, the users must give the surety of their financial transactions which will influence to adopt.
In 2015, the British insurance company Lloyd's estimated that cyber-attacks cost businesses as much as $\$ 400$ billion a year, which includes direct damage plus post-attack disruption to the normal course of business. Some vendor and media forecasts over the past year put the cybercrime figure as high as $\$ 500$ billion and more (Kumar, McKay \& Rotman [31]. Mattila [32] research work on Mobile Banking Services Resistance which investigated the barriers towards Mobile Banking System adoption among young people in Germany established that, compatibility, perceived usefulness, and risk are significant indicators for the adoption of Mobile banking systems in Germany.

Dineshaw and Steven [8] investigated the complex factors that prevent customers from adopting and using mobile banking services in Mauritius. The researchers used a quantitative approach, they also combined the TAM and IDT together with perceived risk and cost construct to investigate perception of $\mathrm{m}$ banking in Mauritius. The study revealed that age, gender and salary had no influence on adoption but rather, Convenience, compatibility and banking needs influenced banking adoption. On the other hand, perceived security risk and reliability were found to be the only obstacles to mobile banking usage but also that m-banking usage is not associated with age, gender and salary.

Conventionally, people kept monies safe by keeping it in a hidden place and guarding it. Current systems of finance management delegate safe keeping through a safeguarded store box. Safe keeping can be designated through opening a record in a bank or a nonbank, for example, Mpesa [33].

As stated by Abong'o, [34] study on the effect of mobile phone banking on performance of Commercial Banks in Kenya, in Mpesa as mobile money storage facilitates investing and transferring of monies in that the customer can transfer monies directly from his or her Mpesa account to his/her bank account for safekeeping and investment purposes. Records are created to establish who owns the account and how gaining of access to the account takes place. Banks and non-banks have rules and regulations governing them. The government also implements policy to regulate them. Account information is kept in backups in case of theft or destruction. Mpesa keeps depositors money separate from the telecommunication companies' account. This is necessary for safeguarding purposes. Cash merchants carry out account registration.

Omwansa [35] in his report submitted that, Safaricom is not authorized to operate as banks neither are other telecommunication companies in Kenya. And that, the money circulated on Mpesa is deposited at the Commercial Bank of Africa in a physical bank Account. CBA monitors Mpesa daily transactions. Transactions are made or carried out by use of virtual information. He further asserts that moving around with 
cash though unsafe is convenient and suggests the option of current accounts as safe though not convenient especially where access to bank branches is limited. When one walks around with their virtual money, they can withdraw cash anytime at a minimal fee. In addition, no one can access a stolen mobile phone without the correct Personal Identification Number or PIN. Mpesa therefore provides both convenience and safety [35].

According to Donner and Tellez [36] Mbanking and M-payment systems enable users to store value/currency in an account accessible via the handset. Again, mobile phones can be used to convert cash in and out of the stored value account and mobile phones can be used to transfer stored value between accounts. A set of SMS messages, menu commands and pin commands are usually used. They further emphasized that, Storage of monies for safe keeping and depositing of monies are different terms that can be used interchangeably because of their similarities. When one deposits money with Mpesa or with a bank, the Agent or bank keeps the physical monies in exchange for virtual information or as a credit entry in the customer's account if it is a bank. The monies are therefore stored and kept safe. Mobile phones can be used to store values in an account linked to a handset.

Mohamed [37] study on the effect of mobile banking on the financial performance of commercial banks in Kenya established that, the act of depositing monies through the phone offers convenience to the customer. Mobile phone banking is a relatively new technology with storage of monies for safekeeping being one of the mobile banking components. In mobile phone banking, adopters are the banks and the customers in that the banks will offer the products and the customers will choose whether or not to consume it. The banks adopt in order to store and keep the monies safe while customers adopt due to convenience. If an innovation is compatible with individual needs, uncertainty decreases and the rate of adoption increase [37].

\section{ReSEARCH Methodology}

A research design is the general plan of how one goes about answering the research question [38]. This study used a descriptive research design of the banks in Kirinyaga County. This is a research method that collects information of a given subject under study by observing the environment and describing their behaviour as it is to demonstrate the relationships that exist between them.
Target population used in the study was the six registered commercial banks in Kirinyaga County Kenya with 140 employees. From the projected target population, a sample of 62 respondents comprising IT specialists was drawn using census sampling technique. Primary data was obtained from the respondents through a structured questionnaire comprising of closed and open - ended questions. The questionnaire was self-administered to the respondents by drop-and-pick them later.

\section{DAta AnAlysis AND Presentation}

The study used descriptive analysis and inferential statistics to establish the relationship between the variables and financial performance of the commercial banks. Descriptive statistics for the proposed study refers to, the statistical methods, which do not falsify relationships; however, aid in the description of the data [39]. Simple linear regression equation was used to determine the extent of change in independent variable caused change in dependent variable.

\section{ReSUlts AND DisCuSSIONS}

Descriptive statistics are basically summarized and organize characteristics of a data set where a data set is a collection of responses or observations from a sample or entire population. Statistical inference is basically the process of using data analysis to infer properties of an underlying distribution of probability for instance by testing hypotheses and deriving estimates [11]. In this study, the process will begin by diagnostic tests of OLS model, when verified then the researcher will proceed to test the hypotheses and derive the estimates.

Simple linear regression analysis was applied to establish the strength and the magnitude of the relationship between the variables and to test the hypothesized relationships. The hypothesis was tested at $95 \%$ level of confidence in order to draw conclusion. Having computed and ascertained that all the OLS assumptions of normality, strength of relationships, linearity, and homoscedasticity and collinearity diagnostics were fulfilled, multiple regression analysis was then computed. The model summary results estimated to show the explained variations through $\mathrm{R}$ square change between mobile banking agility and performance of commercial banks.

Table-1: Regression Model Summary

\begin{tabular}{|c|c|c|c|c|c|c|c|c|c|}
\hline \multirow[t]{2}{*}{ Model } & \multirow[t]{2}{*}{$\mathbf{R}$} & \multirow{2}{*}{$\begin{array}{c}\text { R } \\
\text { Square }\end{array}$} & \multirow{2}{*}{$\begin{array}{l}\text { Adjusted } \\
\text { R Square }\end{array}$} & \multirow{2}{*}{$\begin{array}{l}\text { Std. Error of } \\
\text { the Estimate }\end{array}$} & \multicolumn{5}{|c|}{ Change Statistics } \\
\hline & & & & & $\begin{array}{c}\text { R Square } \\
\text { Change }\end{array}$ & F Change & df1 & df2 & $\begin{array}{c}\text { Sig. F } \\
\text { Change }\end{array}$ \\
\hline 1 & $.631^{\mathrm{a}}$ & .398 & .354 & .33360 & .398 & 9.085 & 4 & 55 & .000 \\
\hline
\end{tabular}

Source: Research data, (2021) 
The finding indicated that agility of mobile banking explained about $35.4 \%$ of bank performance of the commercial banks in Kirinyaga County, as represented by the $\mathrm{R}$ Square value. The $\mathrm{p}$ - value was 0.000 and resulting to observation that the regression model was well fitted. The implication of the finding was to reject the null hypothesis and conclude that agility of mobile banking had positive effect on the performance of commercial banks in Kirinyaga County.

\section{Conclusion}

Mobile banking agility increased performance of commercial banks and thus enhancing customers' services satisfaction. The cost of mobile banking agility prompts managers to make choice into priority applications of mobile banking agility over others considering the budget constraints and strategic choices in order to build competitive advantage. The study findings showed that, banking application agility was the most influential variable and had a statistically significant and positive effect on bank performance. Consequently, the study submits that, bank management should endeavor to embed collaboration, selfreinvention by putting technology first and change the culture by focusing on the customer.

\section{REFERENCES}

1. Aneesh, M. R., Dileeplal, J., \& MA, A. (2014). An integrated fuzzy weighted SERVQUAL-QFD approach for service quality improvement. Facilities, 3(1.77), 0-103.

2. Cohen, D., \& Prusak, L. (2001). In good company (p. 94). Boston: Harvard Business School Press.

3. Khrawish, H.A. (2011) Determinants of Commercial Banks Performance: Evidence from Jordan. International Research Journal of Finance and Economics. Zarqa University, 5(5), 19-45.

4. Gutierrez, E., \& Singh, S. (2013). What regulatory frameworks are more conducive to mobile banking? Empirical evidence from Findex data. The World Bank.

5. Cudjoe, A., Anim, P., \& Nyanyofio, J. (2015). Journal of Computer and communications: Determinants of Mobile banking adoption in the Ghanaian banking industry. A case of Access Bank Ghana Limited.

6. Gutierrez, E., \& Singh, S. (2013). What regulatory frameworks are more conducive to mobile banking? Empirical evidence from Findex data. The World Bank.

7. Frey, S., Paragi, Z., Campbell, R. M., \& Moór, A. (2010). The radio-loud active nucleus in the "dark lens" galaxy J1218+ 2953. Astronomy \& Astrophysics, 513, A18.

8. Dineshwar, R., \& Steven, M. (2013). An Investigation on Mobile Banking Adoption and Usage: A Case Study of Mauritius. Journal of Monetary Economics, 37(42); 21 - 26.
9. Tiwari, R., Buse, S., \& Herstatt, C. (2006, July). Mobile banking as business strategy: Impact of mobile technologies on customer behaviour and its implications for banks. In 2006 Technology Management for the Global Future-PICMET 2006 Conference (Vol. 4, pp. 1935-1946). IEEE.

10. Kigen, K. P. (2010). "The impact of mobile banking on transaction costs of microfinance institutions", Unpublished MBA Thesis, University of Nairobi.

11. Mugenda, A. G. (2003). "Social Science Research; Theory and Principles" Nairobi: Applied Research \& Training Services

12. Gruen T. W., Summers J. O., \& Acito, F. (2010). Relationship marketing activities, commitment, and membership behaviors in professional associations. Journal of Marketing, 64 (3): 34-49

13. Wachira D., (2010) "Relationship between Financial Performance and Camel Rating of Commercial Banks in Kenya" A Research Project Presented in Partial Fulfillment of the requirements of the degree of Master of Business Administration University of Nairobi School of Business: October.

14. Mutua, R. W. (2013). "Effects of mobile banking on the financial Performance of commercial banks in Kenya", Unpublished MBA Thesis, University of Nairobi.

15. Bou-Zeid, E., \& El-Fadel, M. (2002). Climate change and water resources in Lebanon and the Middle East. Journal of water resources planning and management, 128(5), 343-355.

16. Kathuo R. W., Rotich, G, and Anyango, W. (2015), "Effects of mobile banking on the financial Performance of banking institutions in Kenya", Unpublished MBA Thesis, University of Nairobi

17. Tchouassi, G. (2019). Can Mobile Phones Really Work to Extend Banking Services to the Unbanked? Empirical Lessons from Selected SubSaharan Africa Countries, International journal of Development Societies, 1(2), 70-81.

18. Clark, T. (2011). The Cambridge introduction to literature and the environment. Cambridge University Press.

19. Okiro, K., \& Ndungu, J. (2013). The impact of mobile and internet banking on performance of financial institutions in Kenya. European Scientific Journal, 9(13).

20. Islam, S., Zeisel, A., Joost, S., La Manno, G., Zajac, P., Kasper, M., ... \& Linnarsson, S. (2014). Quantitative single-cell RNA-seq with unique molecular identifiers. Nature methods, 11(2), 163.

21. Masamila, B. (2014). State of mobile banking in Tanzania and security issues. International Journal of Network Security \& Its Applications, 6(4), 53.

22. Kithaka, E. (2014). "The effect of mobile banking on the financial Performance of commercial banks in Kenya", Unpublished MBA Thesis, University of Nairobi.

23. Muisyo, A., \& Musiega. (2014). "Effects of mobile banking on the financial Performance of 
commercial banks in Kenya”, Unpublished MBA Thesis, University of Nairobi.

24. Kingoo, H. (2011). "The relationship between electronic banking and financial performance of commercial banks in Kenya". Unpublished MBA Thesis, University of Nairobi

25. Munyoki, S. (2015). "Effect of Mobile Banking on the Financial Performance of Banking Institutions in Kenya" The Strategic Business \& Change Journal of Management, 2(98), 1440 - 1457, Oct 30,2015

26. Kingoo, H. (2011). "The relationship between electronic banking and financial performance of commercial banks in Kenya". Unpublished MBA Thesis, University of Nairobi.

27. Mwange, J. A. (2013). The impact of mobile banking on financial performance of commercial banks in Kenya (Doctoral dissertation, University of Nairobi).

28. Kopchik, J. (2011). "Mobile Banking: Rewards and Risks". Supervisory Insights. 5(2); 1-1

29. Ching M. C. Chuan, A. T., Sim, J. J. Kam, H., \& Tan, B. (2016) Factors Affecting Malaysian Mobile Banking Adoption: An Empirical Analysis, International Journal of Network and Mobile Technologies, 2(3)

30. Valverde, S.C., \& Rodriguez, F. (2017). The Determinants of Bank Margins in European Banking. Journal of Banking \& Finance, 31(7): 2043-2063

31. Kumar. K., McKay, C., \& Rotman. S. (2014). "Microfinance and Mobile Banking: The Story' So
Far”. Focus Note No. 62. Washington D.C: CGAP.

32. Mattila, M. (2016). An Exploratory Study of Mobile Banking Services Resistance. International Journal of Mobile Communications 10(4):366-385.

33. Klein, M. U., \& Mayer, C. (2011). Mobile banking and financial inclusion: The regulatory lessons. World Bank Policy Research Working Paper, (5664).

34. Abong, G. O., Ndanyi, V. C. M., Kaaya, A., Shibairo, S. I., Okoth, M. W., \& Lamuka, P. O. (2016). A review of production, post-harvest handling and marketing of sweetpotatoes in Kenya and Uganda.

35. OMWANSA, A. W. (2019). Stochastic Modeling of Bamboo Population Growth and Optimal Harvesting (Doctoral dissertation, Maseno University).

36. Donald R. Cooper, Pamela S. Schindler, (2010). "Business Research Methods", McGraw-Hill/Irwin 4th edition.

37. Mohamed, M. A., Fallahi, A., El-Sokkary, A. M., Salehi, S., Akl, M. A., Jafari, A., \& Cheng, C. (2019). Stimuli-responsive hydrogels for manipulation of cell microenvironment: From chemistry to biofabrication technology. Progress in Polymer Science, 98, 101147.

38. Saunders, M. N. (2010). The management researcher as practitioner.

39. Kothari, S. P., Ramanna, K., \& Skinner, D. J. (2010). Implications for GAAP from an analysis of positive research in accounting. Journal of Accounting and Economics, 50(2-3), 246-286.

Cite This Article: Lydiah Wamucii Karimi \& Josphat K. Kyalo (2021). Agility of Mobile Banking and Performance of Commercial Banks in Kirinyaga County, Kenya. East African Scholars Multidiscip Bull, 4(2), 6-13. 